\title{
The energy production of juvenile Arenicola marina (Polychaeta) under anoxic and hypoxic conditions
}

\author{
Doris Schiedek \& Udo Schöttler \\ Zoologisches Institut der Westfälischen Wilhelms-Universität Münster; \\ Hindenburgplatz 55, D-4400 Münster, Federal Republic of Germany
}

\begin{abstract}
The mode of anaerobic energy production of juvenile Arenicola marina (0-generation) was investigated under experimental conditions and in the biotope. Under experimental anaerobic conditions, juvenile $A$. marina produce energy by the pathways known from the adults and other euryoxic invertebrates with succinate and the volatile fatty acids, acetate and propionate, as main end products. However, the juvenile lugworms are less resistent to anoxia than the adults. The reasons for this might be their small glycogen stores and their limited ability to reduce the metabolic rate. Nevertheless, on the tidal flats the juveniles settle particularly in the area next to the high tide line, which offers such extreme conditions that adult lugworms cannot live there. This different behaviour can be explained by the dissimilar ability to use oxygen at very low partial pressures. Juveniles maintain an aerobic energy metabolism even at a $\mathrm{P}_{\mathrm{wO}_{2}}$ of 15 Torr at which adults are forced to produce energy exclusively by the less effective anaerobic mode. In the field, no indications of an anaerobic energy metabolism were detected in juveniles even after an exposure of 8 hours.
\end{abstract}

\section{INTRODUCTION}

The lugworm Arenicola marina is an important member of the macrozoobenthos, which plays a considerable role in the ecotone Wadden Sea.

Although this polychaete can be found in all areas of the tidal flats, there are some differences in the distribution pattern of its age groups (Thamdrup, 1935; Wohlenberg, 1937; Smidt, 1951; Beukema \& de Vlas, 1979; Pollack, 1979; Reise, 1981). The adults settle predominantly in the middle and lower parts of the tidal flats, whereas the juveniles (0-generation) live closer to the shore. They are often found in high densities just below the high tide line in so called "Brutwatten" (Wohlenberg, 1937) or "nursery beds" (Reise, 1985). These nursery beds are more sheltered than the rest of the tidal flats. There is no competition between adults and juveniles, and predation pressure is low (Witte \& de Wilde, 1979; Reise, 1985).

On the other hand, the area next to the high tide line offers extreme living conditions. There, average exposure is more than ten hours, with the consequence that various physical parameters, such as temperature, salinity or the availability of oxygen, are subject to considerable variations.

At low tide no oxygenic surface water can be pumped, and benthic animals like Arenicola marina that are not able to use atmospheric oxygen have to supply their energy demand via anaerobic pathways, as was shown by several field investigations (Pionetti \& Toulmond, 1980; Schöttler et al., 1984; Schöttler, 1989). 
Under these circumstances, Arenicola marina uses those pathways for anaerobic energy production which are characteristic for all euryoxic invertebrates with the exception of the arthropods (Zebe \& Schöttler, 1986). Glycogen is broken down via malate to the volatile fatty acids, propionate and acetate. Compared with anaerobic glycolysis these pathways are advantageous because the energy yield is nearly doubled. However, compared to aerobic energy production this yield is modest.

Nevertheless, under experimental conditions Arenicola marina can survive periods of anoxia lasting more than four days. The only possible explanation of this phenomenon is that the animals, as a further adaptation, reduce their metabolic rate significantly (Schöttler, 1986), thus being able to outlast periods of anoxia in a state of strongly reduced activity.

In regard to the fact that the juvenile lugworms are in a state of permanent growth and as a consequence have to meet a comparatively high demand for energy, it is surprising that they live in these areas of extended exposure.

This leads to the assumption that there must be special physiological mechanisms in the juvenile Arenicola marina, which enable them to react to hypoxic or anoxic situations at low tide without suffering greater damage to their further development.

In this paper, data of the energy production of juvenile Arenicola marina from both the laboratory and the natural environment are presented.

\section{MATERIAL AND METHODS}

\section{Animals}

Juvenile Arenicola marina (0-generation) were dug out from the tidal flats at List on the island of Sylt (Nordfriesland/FRG). Before being used in the experiments they were kept in tanks with well aerated running artificial seawater $(32 \% \mathrm{~S})$ at $8-10^{\circ} \mathrm{C}$, without sediment and food for a period not extending 5 days. Previous experiments have shown that starvation over this period does not influence the mode of anaerobic metabolism.

\section{Experimental procedure}

\section{Anaerobic incubation}

All experiments were performed at $12{ }^{\circ} \mathrm{C}$. Prior to their use in the experiments, the worms were adapted to the temperature in well-aerated artificial seawater $(32 \% \mathrm{~S})$ for $24 \mathrm{~h}$. For the incubations, $250-\mathrm{ml}$ round flasks equipped with special fittings for gassing (Schöttler \& Schroff, 1976) were used. The flasks were filled with $150 \mathrm{ml}$ of the artificial seawater and gassed for $30 \mathrm{~min}$ with nitrogen. Three worms with an average individual weight of $170 \pm 50 \mathrm{mg}$ were added and gassing continued for a further $30 \mathrm{~min}$. Finally, the stop-cocks were closed.

\section{Determination of oxygen uptake and incubation at different $P_{\mathrm{wO}}$}

All gas mixtures were prepared from pure nitrogen and pure oxygen using a gas mixing pump (M1007a, Wösthoff, Bochum, FRG). The oxygen uptake at different $\mathrm{P}_{\mathrm{wO}_{2}}$ was measured in a flow-through system. The animals were incubated in special cham- 
bers without sediment. The rate of oxygen consumption was measured continuously with an Orbisphere oxygen electrode (Model 2115 connected to an oxygen indicator Orbisphere 2609).

\section{Preparations of extracts}

At the end of an incubation period, the worms were rapidly blotted on paper tissue and opened by a lateral incision. After dissection the body-wall musculature was frozen in liquid nitrogen. The frozen material was stored at $-70^{\circ} \mathrm{C}$.

For further extraction, the frozen body-wall musculature was ground to a fine powder in a mortar cooled by liquid nitrogen. The powder was added to 5 vols of ice-cold $3 \mathrm{~mol} / \mathrm{l}$ perchloric acid, stirred until thawing, and homogenized in an Ultra-Turrax homogenizer. After centrifugation (20 min; $30000 \times \mathrm{g}$ ), the supernatant was neutralized by adding $\mathrm{K}_{2} \mathrm{CO}_{3}(5 \mathrm{~mol} / \mathrm{h})$. Special care was taken to avoid alkaline $\mathrm{pH}$. The neutralized extract was centrifuged for $20 \mathrm{~min}$ at $45000 \times \mathrm{g}$. All steps were performed at $0-4{ }^{\circ} \mathrm{C}$.

\section{Measurements of metabolites}

ATP, ADP, AMP, D-and L-alanine, succinate (Bergmeyer, 1984, 1985), phosphotaurocyamine (Pörtner et al., 1979) were estimated by standard enzymatic methods. Extraction and hydrolysis of glycogen were performed according to Schöttler (1978). Volatile fatty acids were measured after steam destillation of the incubation water by gasliquid chromatography (Kluytmans et al., 1975).

Separation and determination of amino acids by HPLC

The amino acids were dansylated (Wiedmeier et al., 1982) and separated on a reverse phase column (Spherisorb ODS $2,5 \mu \mathrm{m}$ ) at a temperature of $55^{\circ} \mathrm{C}$. A multistep gradient eluation was used with a flow rate of $1.0 \mathrm{ml} / \mathrm{min}$. Solvent $A: 50 \mathrm{mmol} / \mathrm{f}$ formic acid and $60 \mathrm{mmol} / \mathrm{l}$ acetic acid, $\mathrm{pH} 3.0$. Solvent B: $50 \mathrm{mmol} / \mathrm{l}$ formic acid, $60 \mathrm{mmol} / \mathrm{l}$ acetic acid, $35 \%$ 2-propanol, pH 2.9. The separated dansyl derivates were detected at $254 \mathrm{~nm}$.

\section{Field investigations}

The field investigations were carried out on the tidal flats to the north of the island of Sylt (Nordfriesland/FRG). Three stations were selected: $\mathrm{A}=$ sand flat, $\mathrm{B}=$ sand-mud flat and $\mathrm{C}=$ mud flat. Juvenile lugworms (0-generation) were dug out as soon as the water had receded and after 8 hours of exposure. They were immediately washed with seawater and quickly dissected. The body-wall musculature was blotted dry and frozen in liquid nitrogen.

Further extraction was carried out as described above.

\section{Statistics}

All results are presented as mean values \pm SD. Significance was determined by Student's $t$-test $\left(t_{0.05}\right)$. 


\section{RESULTS}

\section{Experimental anoxia}

Under anaerobic conditions at $12^{\circ} \mathrm{C}$, juvenile Arenicola marina survived only periods shorter than 48 hours. Therefore, time course experiments were limited to 24 hours.

During the first six hours after onset of anaerobic conditions, the juvenile lugworms

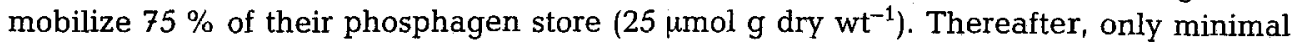
degradation of phosphotaurocyamine occurred (Table 1). The energy charge, which is a

Table 1. Juvenile Arenicola marina. Concentrations of adenine nucleotides and taurocyaminephosphate (TCP) ( $\mu$ moles $\mathrm{g}$ dry $\mathrm{wt}^{-1}$ ) and the calculated energy charge (E.C.) in the body-wall musculature after anaerobic incubation. Mean values $\pm S D, N=4$

\begin{tabular}{|ccccrrrr}
\hline $\begin{array}{c}\text { Incubation } \\
\text { time }(\mathrm{h})\end{array}$ & ATP & ADP & AMP & $\Sigma$ & E.C. & TCP \\
\hline 0 & $7.74 \pm 0.44$ & $2.16 \pm 0.41$ & $0.92 \pm 0.28$ & 10.82 & $0.82 \pm 0.02$ & $27.1 \pm 2.8$ \\
1 & $5.67 \pm 0.28$ & $2.38 \pm 0.74$ & $0.95 \pm 0.25$ & 9.00 & $0.76 \pm 0.01$ & $15.8 \pm 2.7$ \\
6 & $5.22 \pm 0.06$ & $3.34 \pm 0.71$ & $1.58 \pm 0.45$ & 10.14 & $0.68 \pm 0.05$ & $7.0 \pm 3.8$ \\
12 & $5.01 \pm 1.00$ & $3.30 \pm 0.10$ & $2.43 \pm 0.18$ & 10.74 & $0.62 \pm 0.03$ & $5.2 \pm 2.5$ \\
24 & $4.61 \pm 0.90$ & $4.19 \pm 0.51$ & $2.36 \pm 0.32$ & 11.16 & $0.60 \pm 0.01$ & $5.9 \pm 1.5$ \\
\hline
\end{tabular}

sensitive indicator of stress situations, decreased rapidly from 0.82 to 0.70 in the first hours of anoxia and dropped to a value of nearly 0.6 after 24 hours (Table 1). The content of the adenine nucleotides remained constant.

The utilization of aspartate was restricted to the initial stage of anaerobiosis (Fig. 1). In this period, its amount was reduced by at least $50 \%\left(16 \mu \mathrm{mol} \mathrm{g} \mathrm{dry} \mathrm{wt}^{-1}\right)$. D,L-alanine, a glycolytic end product in euryoxic animals, was accumulated (approx. $60 \mu \mathrm{mol} g$ dry $\mathrm{wt}^{-1}$ ) during the first 12 hours of anoxia (Fig. 1). The determination of this amino acid was done by HPLC (High Performance Liquid Chromatography). Using the method described, it was not possible to distinguish the $D$ and $L$ stereoisomere. However, in enzymatic tests it could be shown that in juvenile Arenicola marina both the L- and Dform exist.

As a typical end product of short environmental anaerobiosis, succinate, too, was accumulated during the first 12 hours at an amount of at least $15 \mu \mathrm{mol} \mathrm{g} \mathrm{dry} \mathrm{wt^{-1 }}$ (Fig. 2).

The volatile fatty acids, acetate and propionate, characteristical end products of long environmental anaerobiosis, could only be measured in the incubation water, because the remaining volume of the extracts was too small after determination of the other metabolites. After 6 hours these two fatty acids could be detected in the incubation water for the first time. After 24 hours the ratio of propionate to acetate was 5:1 (Table 2). On the assumption that the body-wall musculature represents $80 \%$ of the animal's tissues, we calculated the quantity of the volatile fatty acids produced by this tissue (Table 3 ). According to this, the share of volatile fatty acids originating from the body-wall musculature and given off to the incubation water amounted to $7 \mu \mathrm{mol} \mathrm{g} \mathrm{dry} \mathrm{wt^{-1 }}$ acetate and $35 \mu \mathrm{mol} \mathrm{g}$ dry $\mathrm{wt}^{-1}$ propionate. 


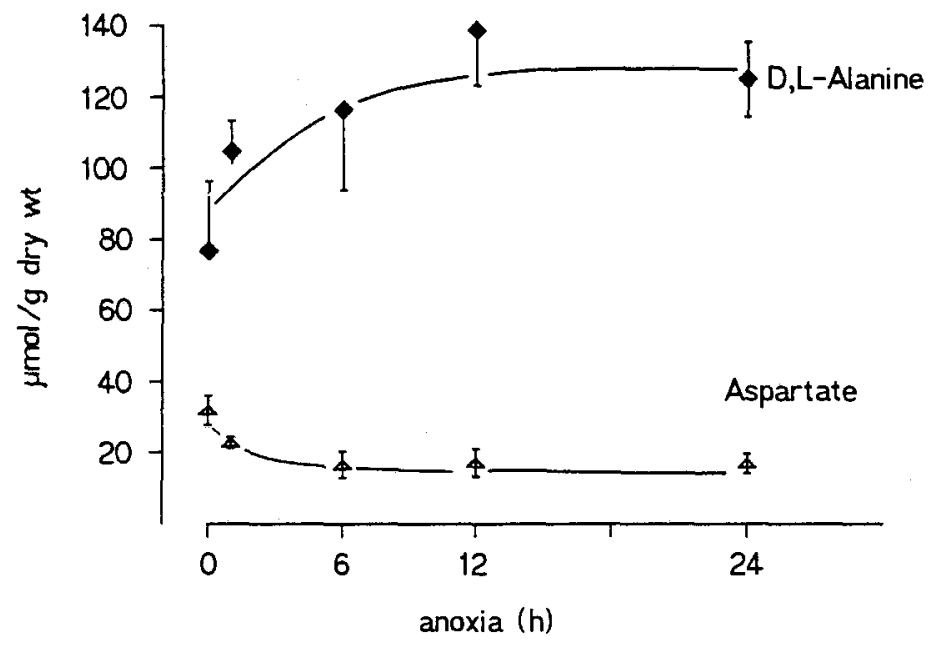

Fig. 1. Juvenile Arenicola marina. Concentration of the amino acids aspartate and D,L-alanine $\left(\mu\right.$ moles $\mathrm{g}$ dry $\left.\mathrm{wt}^{-1}\right)$ after anaerobic incubation. Mean values $\pm \mathrm{SD}, \mathrm{N}=4$

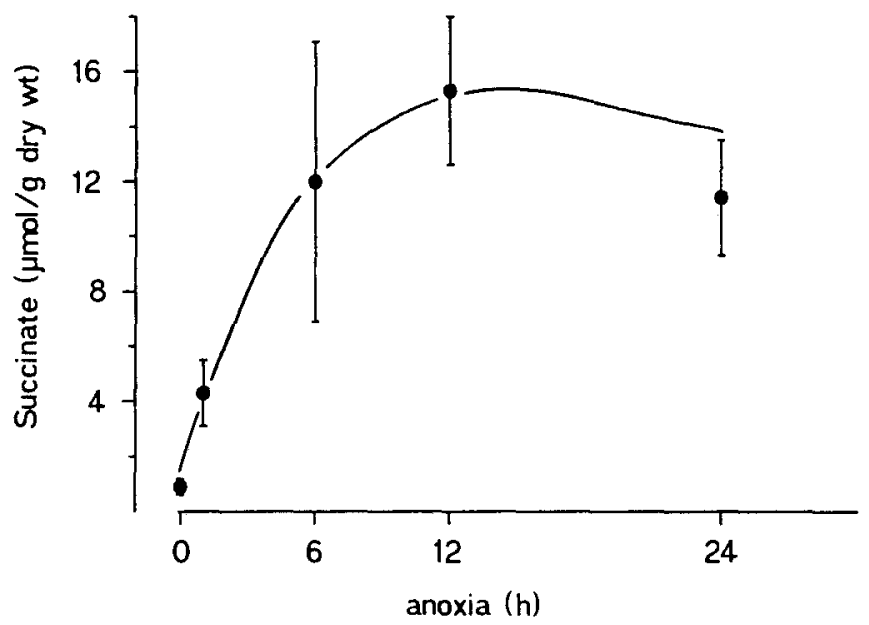

Fig. 2. Juvenile Arenicola marina. Concentration of succinate ( $\mu$ moles $\mathrm{g} \mathrm{dry} \mathrm{wt}^{-1}$ ) after anaerobic incubation. Mean values $\pm \mathrm{SD}, \mathrm{N}=4$

\section{Glycogen}

As shown in Table 4, the glycogen stores of the juvenile Arenicola marina are rather small. In addition to this, the following relation is discernible: with increasing body weight of the juveniles the glycogen content $g$ dry $\mathrm{wt}^{-1}$ increases, too. 
Table 2. Juvenile Arenicola marina. Concentrations of the volatile fatty acids propionate and acetate $\left(\mu\right.$ moles wet $\left.w t^{-1}\right)$ in the incubation water after anaerobic incubation. Mean values $\pm S D, N=4$

\begin{tabular}{|ccc|}
\hline $\begin{array}{c}\text { Incubation } \\
\text { time (h) }\end{array}$ & Acetate & Propionate \\
\hline 0 & - & - \\
1 & - & - \\
6 & $0.08 \pm 0.02$ & $0.25 \pm 0.12$ \\
12 & $0.46 \pm 0.11$ & $1.90 \pm 0.31$ \\
24 & $1.10 \pm 0.30$ & $5.63 \pm 0.43$ \\
\hline
\end{tabular}

Table 3. Juvenile Arenicola marina. Calculated quantity of the volatile fatty acids propionate and acetate ( $\mu$ moles $\mathrm{g}$ dry $\mathrm{wt}^{-1}$ ) produced by the body-wall musculature. Mean values $\pm S D, N=4$

\begin{tabular}{|ccc|}
\hline $\begin{array}{c}\text { Incubation } \\
\text { time }(\mathrm{h})\end{array}$ & Acetate & Propionate \\
\hline 0 & - & - \\
1 & - & - \\
6 & $0.49 \pm 0.12$ & $1.54 \pm 0.74$ \\
12 & $2.83 \pm 0.68$ & $11.70 \pm 1.91$ \\
24 & $6.78 \pm 1.85$ & $34.68 \pm 2.65$ \\
\hline
\end{tabular}

Table 4. Juvenile Arenicola marina. Glycogen content ( $\mu$ moles glycosyl units $\mathrm{g} \mathrm{dry} \mathrm{t}^{-1}$ ) in relation to the individual weight of the worms. Mean values $\pm S D$

\begin{tabular}{|cccccc|}
\hline $\begin{array}{c}\text { Individual } \\
\text { weight }\end{array}$ & $\begin{array}{c}100-200 \mathrm{mg} \\
\mathrm{N}=10\end{array}$ & $\begin{array}{c}200-300 \mathrm{mg} \\
\mathrm{N}=8\end{array}$ & $\begin{array}{c}300-400 \mathrm{mg} \\
\mathrm{N}=9\end{array}$ & $\begin{array}{c}400-500 \mathrm{mg} \\
\mathrm{N}=7\end{array}$ & $\begin{array}{c}500-1000 \mathrm{mg} \\
\mathrm{N}=5\end{array}$ \\
\hline Glycogen & $46.0 \pm 11.0$ & $70.4 \pm 15.9$ & $95.2 \pm 13.7$ & $125.8 \pm 19.8$ & $157.3 \pm 48.0$ \\
\hline
\end{tabular}

\section{Field investigations}

With reference to laboratory experiments, the accumulation of succinate can be regarded as a significant indicator of anaerobic energy production in both juvenile and adult Arenicola marina. By means of this indicator, we examined whether or not anaerobiosis occurs in the natural environment.

Juvenile lugworms were dug out as soon as the water receded $\left(\mathrm{O} \mathrm{h}_{;}\right.$control) and after 8 hours of exposure. This period was chosen with regard to the comparability of these results with published data of adult Arenicola marina (Schöttler et al., 1984; Schöttler, 1989). In all animals prepared $8 \mathrm{~h}$ after exposure, the amount of succinate in the body-wall musculature was only slightly higher than in the controls (Table 5). This result was not influenced by the type of flat, because there was no difference between station $A$ (sand flat), station B (sand-mud flat) and station C (mud flat). Additionally, at all three 
Table 5. Juvenile Arenicola marina. Concentrations of succinate and the amino acids aspartate and $\mathrm{D}, \mathrm{L}$-alanine ( $\mu$ moles $\mathrm{g}$ dry $\left.\mathrm{wt}^{-1}\right)$ in the body-wall musculature at the beginning of low tide $(0 \mathrm{~h})$ and after $8 \mathrm{~h}$ of exposure. Mean values $\pm \mathrm{SD}, \mathrm{N}=10$

\begin{tabular}{|clllr|}
\hline $\begin{array}{c}\text { Time of } \\
\text { exposure }\end{array}$ & & Succinate & Aspartate & D, L-Alanine \\
\hline & station A & $0.70 \pm 0.15$ & $40.2 \pm 6.1$ & $78.5 \pm 13.3$ \\
$0 \mathrm{~h}$ & station B & $0.89 \pm 0.27$ & $36.8 \pm 9.3$ & $79.4 \pm 8.9$ \\
& station C & $0.75 \pm 0.21$ & $41.4 \pm 7.8$ & $66.5 \pm 9.8$ \\
& station A & $2.56 \pm 1.80$ & $35.3 \pm 9.6$ & $89.3 \pm 13.9$ \\
& station B & $3.04 \pm 2.20$ & $28.1 \pm 10.9$ & $90.4 \pm 17.6$ \\
& station C & $2.15 \pm 0.74$ & $35.9 \pm 6.7$ & $76.9 \pm 15.6$ \\
\hline
\end{tabular}

stations no significant changes in the amounts of the amino acids aspartate and D,Lalanine were determined (Table 5).

Determination of oxygen uptake and incubation at different $\mathrm{P}_{\mathrm{wO}_{2}}$

The data obtained in the field induced further laboratory experiments. For a period of 24 hours we measured the oxygen uptake at different $\mathrm{P}_{\mathrm{wO}_{2}}$. Under normoxic conditions, juvenile lugworms consume $2 \mu \mathrm{mol} \mathrm{O} \mathrm{gfw}^{-1} \mathrm{~h}^{-1}$ (Fig. 3). From a $\mathrm{P}_{\mathrm{wO}_{2}}$ of 120 Torr down to 8 Torr the oxygen consumption is reduced constantly, but even at a $\mathrm{P}_{\mathrm{wO}_{2}}$ of 8 Torr it amounts to a quarter of its value under normoxic conditions.

These data were completed by investigation of the lowest $\mathrm{P}_{\mathrm{wO}_{2}}$ at which juvenile Arenicola marina are able to maintain an aerobic metabolism. As in the experiments described above, the animals were exposed for 24 hours to different $\mathrm{P}_{\mathrm{wO}_{2}}$. Although the phosphagen store was mobilized and the energy charge dropped from 0.86 to 0.78 at a

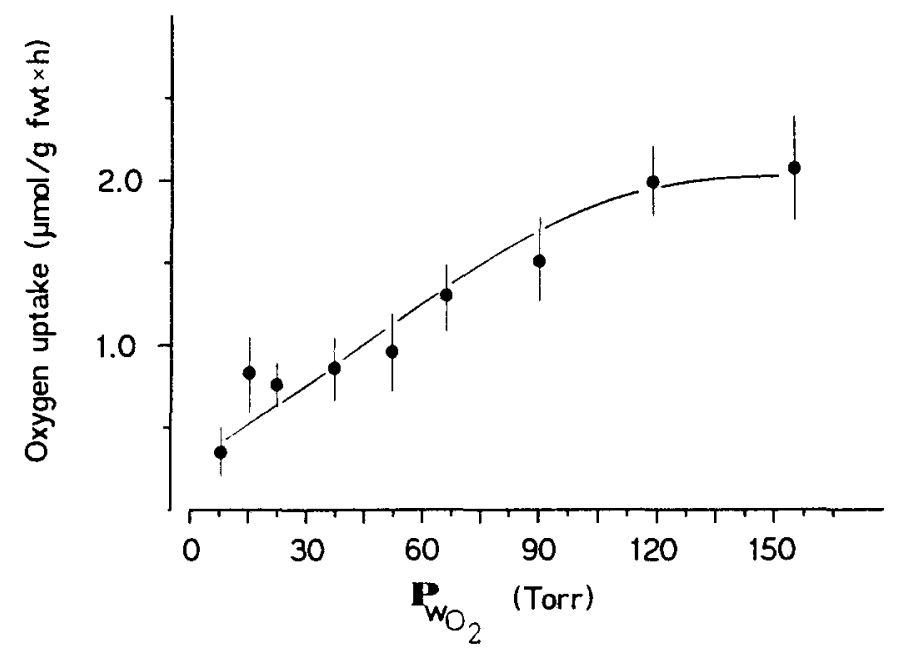

Fig. 3. Juvenile Arenicola marina. Oxygen consumption at different $\mathrm{P}_{\mathrm{wO}_{2}}$ 
$\mathrm{P}_{\mathrm{wO}_{2}}$ of 30 Torr (Table 6), the first clear sign for the shift to anaerobic metabolism was found at a $\mathrm{P}_{\mathrm{wO}_{2}}$ of 15 Torr. At this $\mathrm{P}_{\mathrm{wO}_{2}}$ a significant degradation of aspartate and a significant accumulation of $D, L$-alanine and succinate occurred (Figs 4,5 ). This became more obvious at an $\mathrm{P}_{\mathrm{wO}_{2}}$ of 8 Torr. At this oxygen pressure, the volatile fatty acids, acetate and propionate, were detectable for the first time in the incubation water (Tables 7, 8). Even under these severe hypoxic conditions, however, the extent of anaerobic energy production was much lower than under anoxic conditions.

\section{DISCUSSION}

The experimental data on anoxia demonstrate that juvenile Arenicola marina use the same pathways of anaerobic energy production as the adults (Review: Schöttler, 1986). Considering the time of sustaining anoxia, it is remarkable that the juvenile A. marina

Table 6. Juvenile Arenicola marina. Concentrations of the adenine nucleotides and taurocyaminephosphate (TCP) ( $\mu$ moles $g$ dry $w^{-1}$ ) and the calculated energy charge (E.C.) in the body-wall musculature after $24 \mathrm{~h}$ of incubation at different $\mathrm{P}_{\mathrm{wO}_{2}}$. Mean values $\pm \mathrm{SD}, \mathrm{N}=4$

\begin{tabular}{|ccccccc|}
\hline $\begin{array}{c}\mathrm{P}_{\text {wO }} \\
\text { (Torr) }\end{array}$ & ATP & ADP & AMP & $\Sigma$ & E.C. & TCP \\
\hline Normoxic & $6.38 \pm 0.57$ & $1.74 \pm 0.36$ & $0.36 \pm 0.14$ & 8.48 & $0.86 \pm 0.02$ & $30.4 \pm 3.8$ \\
30 & $6.05 \pm 0.30$ & $2.85 \pm 0.46$ & $0.66 \pm 0.21$ & 9.56 & $0.78 \pm 0.02$ & $10.5 \pm 3.5$ \\
15 & $5.54 \pm 0.39$ & $2.35 \pm 0.41$ & $1.31 \pm 0.16$ & 9.20 & $0.73 \pm 0.02$ & $10.1 \pm 4.5$ \\
8 & $5.48 \pm 0.29$ & $2.98 \pm 0.33$ & $1.02 \pm 0.25$ & 9.48 & $0.74 \pm 0.02$ & $11.4 \pm 3.9$ \\
Anoxic & $4.66 \pm 0.77$ & $3.92 \pm 0.92$ & $1.56 \pm 0.35$ & 10.14 & $0.65 \pm 0.06$ & $8.6 \pm 1.8$ \\
\hline
\end{tabular}

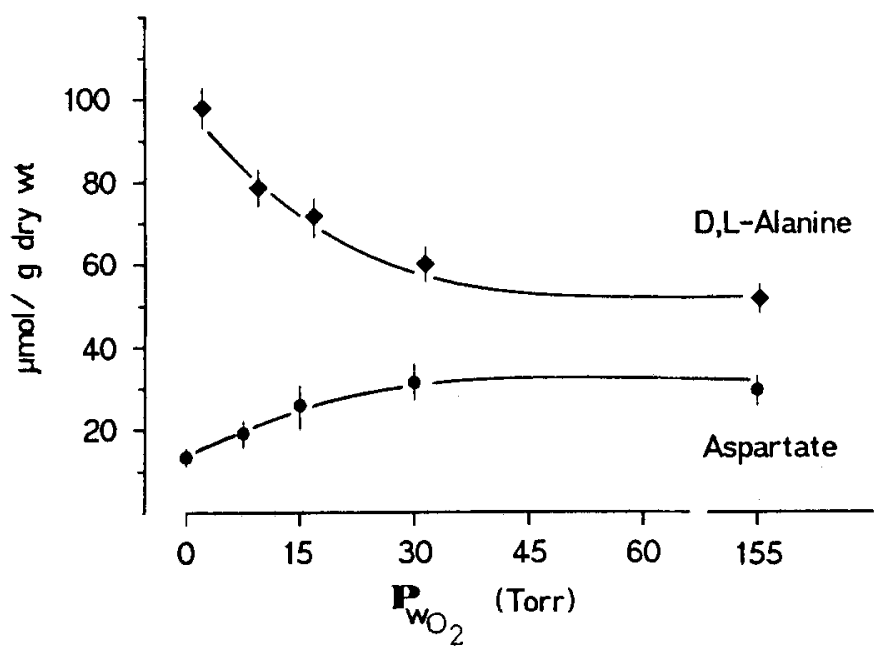

Fig. 4. Juvenile Arenicola marina. Concentration of the amino acids aspartate and D,L-alanine ( $\mu$ moles $\mathrm{g}$ dry $\mathrm{wt}^{-1}$ ) in the body-wall musculature after $24 \mathrm{~h}$ of incubation at different $\mathrm{P}_{w_{2}}$. Mean values $\pm \mathrm{SD}, \mathrm{N}=4$ 


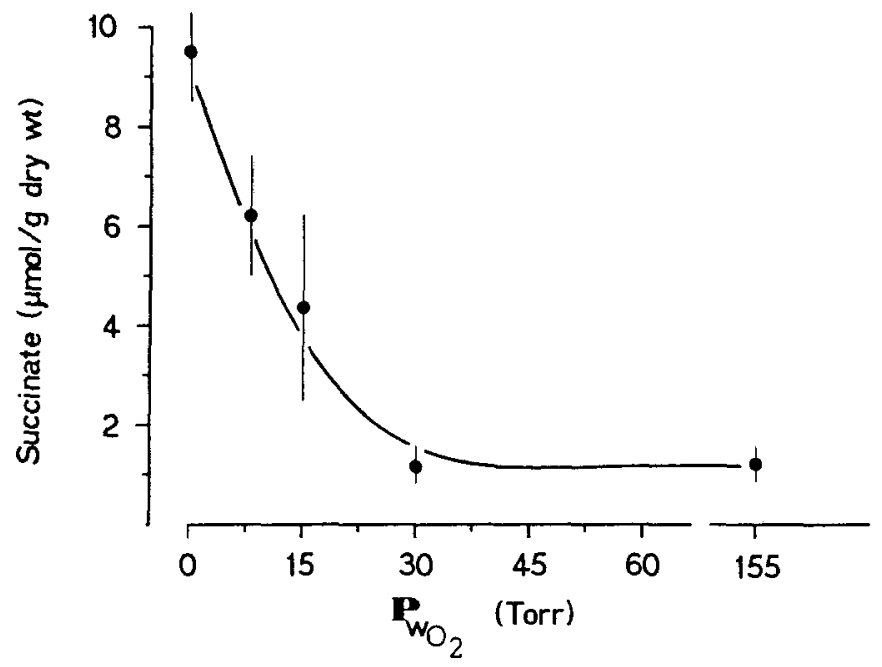

Fig. 5. Juvenile Arenicola marina. Concentration of succinate ( $\mu$ moles $g$ dry $\left.w^{-1}\right)$ in the body-wall musculature after $24 \mathrm{~h}$ of incubation at different $\mathrm{P}_{\mathrm{wO}_{2}}$. Mean values $\pm S D, N=4$

Table 7. Juvenile Arenicola marina. Concentrations of the volatile fatty acids propionate and acetate ( $\mu$ moles wet $\mathrm{wt}^{-1}$ ) in the incubation water after $24 \mathrm{~h}$ of incubation at different $\mathrm{P}_{\mathrm{wO}_{2}}$. Mean values \pm $\mathrm{SD}, \mathrm{N}=4$

\begin{tabular}{|ccc|}
\hline $\begin{array}{c}\mathrm{P}_{\mathrm{wO}_{2}} \\
(\mathrm{Torr})\end{array}$ & Acetate & Propionate \\
\hline Normoxic & - & - \\
30 & $0.08 \pm 0.02$ & - \\
15 & $0.09 \pm 0.05$ & $0.10 \pm 0.02$ \\
8 & $0.19 \pm 0.07$ & $0.60 \pm 0.54$ \\
Anoxic & $0.78 \pm 0.44$ & $5.75 \pm 1.08$ \\
\hline
\end{tabular}

Table 8. Juvenile Arenicola marina. Calculated quantity of the volatile fatty acids propionate and acetate ( $\mu$ moles $\mathrm{g} \mathrm{dry}^{-1} \mathrm{wt}^{-1}$ ) produced by the body-wall musculature after $24 \mathrm{~h}$ of incubation at different $\mathrm{P}_{\mathrm{wO}_{2}}$. Mean values $\pm \mathrm{SD}, \mathrm{N}=4$

\begin{tabular}{|ccc|}
\hline $\mathrm{P}_{\mathrm{wO}_{2}}$ & Acetate & Propionate \\
(Torr) & & - \\
\hline Normoxic & - & - \\
30 & $0.49 \pm 0.12$ & $0.62 \pm 0.12$ \\
15 & $0.55 \pm 0.31$ & $3.70 \pm 3.30$ \\
8 & $1.17 \pm 0.43$ & $35.42 \pm 6.65$ \\
\hline
\end{tabular}


turned out to be less resistent than the adults. One reason for this might be the fact that the glycogen stores of the juveniles are considerably smaller. (The size of the stores are obviously dependent on the weight of the worms and consequently on their age.) However, the drastic decrease in the energy charge even in the first few hours of anaerobiosis indicates that the small glycogen stores are only one factor and one that has a limiting effect solely during prolonged anoxia.

The energy charge drops more rapidly than in adult lugworms although the juveniles produce energy in the same quantities as were found in adults (Schöttler, 1986). Obviously, juvenile Arenicola marina are not able to reduce their energy demand to the same extent as the adults. This may be caused by the predominance of anabolic metabolism in the juveniles.

From this point of view it seemed incomprehensible that juvenile Arenicola marina show only a slight tendency for anaerobiosis in their biotope even after prolonged exposure. Adult lugworms, however, who as a rule do not settle in such exposed areas produce energy anaerobically during low tide (Pionetti \& Toulmond, 1980; Schöttler et al., 1984; Schöttler, 1989).

This apparent inconsistency could be explained when the oxygen consumption had been determined. Under normoxic conditions, juvenile Arenicola marina clearly use more oxygen than the adults. Adults have a similar high oxygen consumption only at times when their reproductive cells are developing (Schöttler, 1989).

At reduced $\mathrm{P}_{\mathrm{wO}_{2}}$ both adults and juveniles react as oxyconformers, i.e. the oxygen consumption depends on the $\mathrm{P}_{\mathrm{wO}_{2}}$. However, under strong hypoxia the reduction of oxygen consumption is significantly lower in juveniles than that found in the adults (Toulmond, 1975). This correlates with the fact that juvenile Arenicola marina do not start to accumulate the typical end products of anaerobiosis, until a $\mathrm{P}_{\mathrm{wO}_{2}}<20$ Torr is reached. Even at a $\mathrm{P}_{\mathrm{wO}_{2}}$ of 8 Torr, only a part of their energy is produced anaerobically. However, at such a low $\mathrm{P}_{\mathrm{wO}_{2}}$, they have to reduce the metabolic rate to $25 \%$. Even then, energy production is more effective than under anaerobic conditions. In contrast, adult $A$. marina must completely switch over to anaerobic energy production at a $\mathrm{P}_{\mathrm{wO}}$ of 15 Torr (Schöttler et al., 1983). The reasons for such differences in the use of oxygen at low $\mathrm{P}_{\mathrm{wO}_{2}}$ can only be speculated on. Both adults and juveniles take up oxygen not only across the gills but also through the whole body surface. In juveniles, however, the ratio between surface area and body volume is relatively higher and, besides, the body-wall is considerably thinner. This may be the reason for the better utilization of oxygen by the juveniles at low $\mathrm{P}_{\mathrm{wO}_{2}}$.

From the data reported in this study, it can be concluded that the successful settlement of juvenile Arenicola marina in such nursery beds cannot only be explained by ecological factors, such as minor intra- and interspecific competition, limited predation and sufficient food resources, but is also based on specific physiological adaptations such as the described remarkable ability to use oxygen for energy production even at very low $\mathrm{P}_{\mathrm{wO}_{2}}$.

For permanent settlement in such extreme areas, this ability seems to be a crucial prerequisite that guarantees a continuous development. 
Acknowledgements. This work was supported by the Deutsche Forschungsgemeinschaft. Parts of this work were carried out at the Biologische Anstalt Helgoland, Wattenmeerstation List/Sylt. We are grateful to the staff of the Wattenmeerstation for their helpfulness and for stimulating and critical discussions.

\section{LITERATURE CITED}

Bergmeyer, H. U., 1984. Methods of enzymatic analysis. Verl. Chemie, Weinheim, 6, 1-701. Bergmeyer, H. U., 1985. Methods of enzymatic analysis. Verl. Chemie, Weinheim, 7, 1-641.

Beukema, J. J. \& Vlas, J. de, 1979. Population parameters of the lugworm Arenicola marina, living on the tidal flats in the Dutch Wadden Sea. - Neth. J. Sea Res. 13, 331-353.

Kluytmans, J. H., Veenhof, P. R. \& Zwaan, A. de, 1975. Anaerobic production of volatile fatty acids in the sea mussel, Mytilus edulis (L.). - J. comp. Physiol. 104, 71-78.

Pionetti, J. M. \& Toulmond, A., 1980. Tide-related changes of volatile fatty acids in the blood of the lugworm Arenicola marina (L.) - Can. J. Zool. 58, 1722-1726.

Pollack, H., 1979. Population dynamics, productivity and energetics of the lugworm Arenicola marina (Annelida, Polychaeta). - Helgoländer wiss. Meeresunters. 32, 313-358.

Pörtner, H. O., Surholt, B. \& Grieshaber, M., 1979. Recovery from anaerobiosis of the lugworm Arenicola marina L.: Changes of metabolites concentrations in the body-wall musculature. J. comp. Physiol. 133, 227-231.

Reise, K., 1981. Ökologische Experimente zur Dynamik und Vielfalt der Bodenfauna in den Nordseewatten. - Verh. dt. zool. Ges. 1981, 1-15.

Reise, K., 1985. Tidal flat ecology. Springer, Berlin, $191 \mathrm{pp}$.

Schöttler, U., 1978. Investigations of the anaerobic metabolism of the polychaete worm Nereis diversicolor M. - J. comp. Physiol. 125, 185-189.

Schöttler, U., 1986. Weitere Untersuchungen zum anaeroben Energiestoffwechsel des Polychaeten Arenicola marina L. -- Zool. Beitr. 30, 141-152.

Schöttler, U., 1989. Anaerobic metabolism in the lugworm Arenicola marina during low tide: the influence of developing reproductive cells. - Comp. Biochem. Physiol. 92 (A), 1-7.

Schöttler, U. \& Schroff, G., 1976. Untersuchungen zum anaeroben Glykogen-Abbau bei Tubifex tubifex. - J. comp. Physiol. 108, 243-254.

Schöttler, U., Wienhausen, G. \& Zebe, E., 1983. The mode of energy production in the lugworm Arenicola marina at different oxygen concentrations. - J. comp. Physiol, 149, 547-555.

Schöttler, U., Surholt, B. \& Zebe, E., 1984. Anaerobic metabolism in Arenicola marina and Nereis diversicolor during low tide. - Mar. Biol. 81, 69-73.

Smidt, E. L., 1951. Animal production in the Danish Wadden Sea. - Meddr Kommn Danm. Fisk-og Havunders, 11, 1-151.

Thamdrup, H. M., 1935. Beiträge zur Ökologie der Wattfauna auf experimenteller Grundlage. Meddr Kommn Danm. Fisk-og Havunders, 10 (2), 1-125.

Toulmond, A., 1975. Blood oxygen transport and metabolism of the confined lugworm Arenicola marina (L.). - J. exp. Biol. 63, 647-660.

Wiedmeyer, V. T., Porterfield, S. P. \& Hendrich, C. E., 1982. Quantitation of dns-amino acids from the body tissues and fluids using high performance liquid chromatography. - J. Chromat. 231, 410 .

Witte, F. \& Wilde, P. A. W. de, 1979. On the ecological relation between Nereis diversicolor and juvenile Arenicola marina. - Neth. J. Sea Res. 13, 394-405.

Wohlenberg, E., 1937. Die Wattenmeer-Lebensgemeinschaft im Königshafen von Sylt. - Helgoländer wiss. Meeresunters. 1, 1-92.

Zebe, E. \& Schöttler, U., 1986. Vergleichende Untersuchungen zur umweltbedingten Anaerobiose. Zool. Beitr. 30, 125-140. 